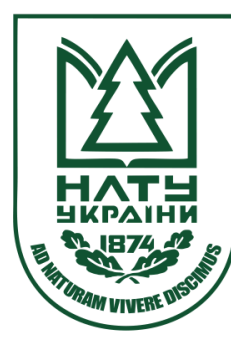

Науковий вісник НлтУ України

Scientific Bulletin of UNFU

ISSN 1994-7836 (print)

https://nv.nltu.edu.ua

https://doi.org/10.36930/40300511

Article received 03.11.2020 p.

Article accepted 16.10.2020 p.

UDC 338.012:502

@ Correspondence author

N. M. Grynchyshyn

nata_gryn123@ukr.net

Н. М. Гринчишин

Львівський державний університет безпеки життєдіяльності, м. Львів, Украйна

\title{
ЕФЕКТИВНІСТЬ МЕТОДИК ДЛЯ РОЗРАХУНКУ ЗБИТКІВ ВІД ЗАБРУ ДНЕННЯ ЗЕМЕЛЬ В УКРАЇНІ
}

Економічний механізм управління екологобезпечним природокористуванням передбачає компенсацію екологічного збитку від забруднення природних ресурсів. У нормативно-методичній базі України для оцінювання екологічного збитку від забруднення природних ресурсів сформовані два напрямки: оцінка збитку через порушення природоохоронного законодавства та оцінка збитку від наслідків надзвичайних ситуацій. Серед чинних методик з оцінювання збитку від забруднення природних ресурсів $є$ різні методики для розрахунку збитків від забруднення земель. До актуальних належить дослідження порівняльної ефективності методик розрахунку збитків від забруднення земель. Серед чинників процесу формування економічного збитку від забруднення важливе місце належить чинникам впливу і сприйняття, які визначають екологічний збиток. За допомогою здійсненого аналізу показників процесу формування екологічного збитку встановлено оцінювальні підходи до розрахунку збитків у різних методиках. Так, методика для розрахунку збитків від забруднення земель через порушення екологічного законодавства визначає прямий збиток від забруднення земель, а методики розрахунку збитків від забруднення земель для оцінювання наслідків надзвичайних ситуацій спрямовані на визначення опосередкованого збитку, а саме, збитку від забруднення підземних вод. Використовуючи опис подій техногенного характеру доведено неефективність методик для розрахунку опосередкованого збитку від забруднення земель. За результатами проведеного дослідження, рекомендуємо в Україні для оцінювання економічного збитку від забруднення земель використовувати одну, ефективнішу методику, яку розроблено для розрахунку збитків від забруднення земель через порушення природоохоронного законодавства.

Ключові слова: земельні ресурси; екологічний збиток; економічна оцінка збитку від забруднення; чинники впливу і сприйняття.

\section{Вступ}

Система економічного механізму управління екологобезпечним природокористуванням передбачає компенсацію завданого екологічного збитку від забруднення. Проблема оцінювання збитку від забруднення навколишнього середовища є центральною в еколого-орієнтованій економіці, спрямована на реалізацію принципів сталого розвитку [10]. Вартісне оцінювання збитку особливо актуальне для країн, які розвиваються, оскільки,рівень забруднення в них зростає найбільш стрімко [9].

У світовій практиці використання грошових методів оцінювання економічних збитків набуло істотного поширення тільки наприкінці XX ст. У європейському законодавстві немає жодних урядово затверджених нормативних актів щодо екологічної політики СС, які б зобов'язували до однозначного використання тих чи інших конкретних методів оцінювання збитків. Наявні методики розрахунку економічних збитків практично різні у кожній країні і відрізняються за підходами до оптимального обчислення загальної суми екологічних збитків [12].

У нормативно-методичній базі України для оцінювання екологічного збитку від забруднення природних ресурсів сформовані два напрями: оцінка збитку через порушення природоохоронного законодавства та оцінка збитку від наслідків надзвичайних ситуацій. Серед чинних методик з оцінювання збитку від забруднення природних ресурсів існують різні методики для розрахунку збитків від забруднення земель.

Практика оцінювання збитків показує, що застосовуючи різні оцінювальні підходи до одного й того самого об'єкта, не завжди можна отримати однакові результати [10]. Враховуючи зазначене вище й для усунення непорозумінь щодо розміру збитків від забруднення земель, розрахованих за різними методиками, актуальними є дослідження з визначення дещо ефективнішої методики серед наявних.

Зважаючи на те, що економічний збиток від забруднення формується під впливом певних чинників, серед яких важливе місце належить чинникам процесу формування екологічного збитку, то завдання дослідження полягало у порівнянні ефективності чинних методик для розрахунку збитку від забруднення земель за оцінювальними підходами визначення екологічного збитку.

Об'єкт дослідження - розрахунок екологічного збитку від забруднення земель.

Предмет дослідження - показники процесу формування екологічного збитку від забруднення земель.

Мета роботи - встановлення оцінювальних підхо-

\section{Інформація про автора:}

Гринчишин Наталія Миколаївна, канд. с.-г. наук, доцент, кафедра екологічної безпеки. Email: nata_gryn123@ukr.net; https://orcid.org/0000-0002-7631-6023

Цитування за ДСТУ: Гринчишин Н. М. Ефективність методик для розрахунку збитків від забруднення земель в Україні. Науковий вісник НЛТУ України. 2020, т. 30, № 5. С. 66-70.

Citation APA: Grynchyshyn, N. M. (2020). The effectiveness of the methodology for calculating the damage from land pollution in Ukraine. Scientific Bulletin of UNFU, 30(5), 66-70. https://doi.org/10.36930/40300511 
дів щодо визначення екологічного збитку на підставі аналізу показників процесу формування екологічного збитку в чинних методиках розрахунку збитку від забруднення земель для обгрунтування ефективнішої методики.

Для досягнення зазначеної мети сформульовано такі основні завдання дослідження:

- визначити основні показники процесу формування екологічного збитку від забруднення земель для різних оцінювальних підходів розрахунку збитку від забруднення земель;

- проаналізувати показники процесу формування екологічного збитку від забруднення земель у чинних методиках;

- з'ясувати оцінювальні підходи для визначення екологічного збитку в чинних методиках розрахунку збитків від забруднення земель;

- порівняти ефективність методик для розрахунку збитків від забруднення земель, використовуючи опис надзвичайних подій техногенного характеру, та обгрунтувати ефективнішу методику.

Наукова новизна отриманих результатів дослідження - вперше застосовано системний підхід і факторний аналіз для порівняльної ефективності методик розрахунку збитку від забруднення земель.

Практична значущість результатів дослідження запропонована дещо ефективніша методика для розрахунку збитку від забруднення земель, яку в подальшому можна використовувати як єдину (міжвідомчу) методику для оцінювання збитку не тільки через порушення природоохоронного законодавства, а й оцінювання збитку від наслідків надзвичайних ситуацій.

Матеріали та методи дослідження. Матеріалами для дослідження були: "Методика визначення розмірів шкоди, зумовленої забрудненням і засміченням земельних ресурсів через порушення природоохоронного законодавства" [7], окремі методики для розрахунку збитків від забруднення земель нафтопродуктами та іншими речовинами (окрім нафтопродуктів) у "Методиці оцінки збитків від наслідків надзвичайних ситуацій техногенного і природного характеру" [6]. У процесі дослідження використали системний підхід, застосовували метод аналізу, порівняння й узагальнення.

Аналіз останніх досліджень та публікацій. Значний науковий внесок у дослідження загальних проблем визначення збитків від забруднення природних ресурсів зробили українські вчені: О. Балацький, М. Бєлуха, М. Бублик, О. Веклич, С. Волошин, Б. Данилишин, С. Дорогунцов, К. Зубко, І. Комарницький, В. Колмакова, О. Крайник, О. Кузьмін, Л. Мельник, Й. Петрович, Ю. Стадницький, В. Трегобчук, Л. Федулова, С. Харічков, М. Хвесик, С. Хлобистов, С. Яковлев та ін.

Особливої уваги заслуговують публікації: К. Зубко [10], присвячені методичним підходам оцінювання еколого-економічних збитків у світі та Україні; О. Веклич [11] і В. Колмакової [3], в яких обгрунтовано потребу екосистемного підходу в оцінюванні збитків від забруднення природних ресурсів; М. Бублик, О. Сипливчак, О. Кузьмін, О. Рибицької, Т. Коропецької [2, 4, 1], в яких розглянуто проблеми економічного оцінювання збитків від надзвичайних ситуацій техногенного характеру. В. Колмакова [3] вказала на проблему неузгодженості чинних методик для розрахунку збитків від забруднення водних ресурсів.

Проаналізувавши наукові публікації, з'ясовано, що науковці в Україні приділяють багато уваги теоретич- ним основам формування еколого-економічних збитків. Дослідження проблеми неузгодженості чинних методик для оцінювання збитків від забруднення земельних ресурсів, відсутні.

\section{Результати дослідження та їх обговорення}

Економічний збиток від забруднення формується під впливом певних чинників (рисунок). Чинники впливу і сприйняття у системі еколого-економічного збитку відображають власне екологічний збиток.

\begin{tabular}{|c|c|c|}
\hline \multicolumn{3}{|c|}{$\begin{array}{l}\text { Чинники формування економічного збитку } \\
\text { від забруднення }\end{array}$} \\
\hline 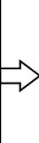 & \begin{tabular}{|l|} 
Виливу: \\
визначають вид забруднення, \\
кількість та небезпечність \\
забруднювальних агентів
\end{tabular} & \multirow{2}{*}{\begin{tabular}{|c|}
$\begin{array}{c}\text { Екологічний } \\
\text { збиток }\end{array}$ \\
\end{tabular}} \\
\hline & \begin{tabular}{|l} 
Сприйняття: \\
характеризують параметри \\
забруднення реципієнта
\end{tabular} & \\
\hline & Іображ & \\
\hline
\end{tabular}

Рис. 1. Чинники формування економічного збитку від забруднення

Отже, економічні збитки від забруднення природних ресурсів - це система показників процесу формування збитків, які використовують у методиках оцінювання збитків. Для розрахунку збитку від забруднення може бути використано прямий і опосередкований оцінювальні підходи до визначення екологічного збитку.

Прямий економічний збиток відображає безпосередній вплив чинників забруднення на первинний об'єкт сприйняття, характеризується територіальністю й переважно документально підтверджений [5]. Результати оцінювання прямих збитків, заподіяні природним ресурсам в надзвичайних ситуаціях, $є$ підставою для звернення суб'єктів господарювання в страхові організації для отримання відшкодування збитків [8].

Опосередкований екологічний збиток $є$ наслідком прямого збитку, більш тривалий і пов'язаний з віддаленими наслідками. Опосередкований збиток, на відміну від прямого, може проявитися через тривалий проміжок часу, від моменту первинного забруднення, і часто не має чітко вираженої територіальної приналежності [5].

Забруднення земель - це накопичення в грунтах i грунтових водах внаслідок антропогенного впливу пестицидів і агрохімікатів, важких металів, радіонуклідів та інших речовин, вміст яких перевищує природний фон, що призводить до їх кількісних або якісних змін [7]. Опосередкований збиток від забруднення земель полягає у забрудненні грунтових вод. Отже, показники процесу формування прямого й опосередкованого екологічного збитку від забруднення земель різні (табл. 1).

Відповідно до "Методики визначення розмірів шкоди, зумовленої забрудненням і засміченням земельних ресурсів через порушення природоохоронного законодавства" [7], розмір шкоди від забруднення земель визначають за такою формулою:

$$
P_{\amalg I}=A \cdot \Gamma_{O 3} \cdot \Pi_{Д} \cdot K_{3} \cdot K_{H} \cdot K_{E \Gamma},
$$

де: $P_{\amalg}-$ розмір шкоди від забруднення земель, грн; $A-$ питомі витрати на ліквідацію наслідків забруднення земельної ділянки, значення якого дорівнює 0,$5 ; \Gamma_{O 3}-$ нормативна грошова оцінка земельної ділянки, що зазнала забруднення, грн/м²; П д площа забрудненої зе- 
мельної ділянки, м²; $K_{3}-$ коефіцієнт забруднення земельної ділянки, що характеризує кількість забруднювальної речовини в об'ємі забрудненої землі залежно від глибини просочування; $K_{H}-$ коефіцієнт небезпечності забруднювальної речовини; $K_{E T}-$ коефіцієнт еколого-господарського значення земель.

Табл. 1. Основні показники процесу формування прямого і опосередкованого екологічного збитку від забруднення земель

\begin{tabular}{|c|c|}
\hline Показник чинників впливу & $\begin{array}{c}\begin{array}{c}\text { Показник чинників } \\
\text { сприйняття }\end{array} \\
\end{array}$ \\
\hline \multicolumn{2}{|c|}{ Прямий збиток } \\
\hline $\begin{array}{l}\text { Маса забруднювальної речовини, } \\
\text { що проникла у товщу земельного } \\
\text { шару } \\
\text { Концентрація забруднювальної ре- } \\
\text { човини у товщі земельного шару } \\
\text { Небезпечність забруднювальної ре- } \\
\text { човини }\end{array}$ & $\begin{array}{l}\text { Площа земельної ділян- } \\
\text { ки, яка зазнала забруд- } \\
\text { нення } \\
\text { Глибина проникнення } \\
\text { забруднювальної речо- } \\
\text { вини у товщу земельного } \\
\text { шару }\end{array}$ \\
\hline \multicolumn{2}{|c|}{ Опосередкований збиток } \\
\hline $\begin{array}{l}\text { Маса забруднювальної речовини, } \\
\text { що надійшла у підземні води } \\
\text { Концентрація забруднювальної ре- } \\
\text { човини у підземних водах } \\
\text { Небезпечність забруднювальної ре- } \\
\text { човини }\end{array}$ & $\begin{array}{l}\text { Об'єм забруднених під- } \\
\text { земних вод }\end{array}$ \\
\hline
\end{tabular}

Відповідно до "Методики оцінювання збитків від наслідків надзвичайних ситуацій техногенного і природного характеру" [6] розмір збитку від забруднення земель визначають для певних типів і видів надзвичайних ситуацій (табл. 2).

Табл. 2. Збитки від забруднення земель (3ф), характерні для різних типів і рівнів надзвичайних ситуацій

\begin{tabular}{|c|c|c|c|c|}
\hline \multirow[b]{2}{*}{ Тип НС } & \multicolumn{4}{|c|}{ Рівень НC } \\
\hline & $\begin{array}{c}\text { об'єкто- } \\
\text { вий }\end{array}$ & $\begin{array}{l}\text { місце- } \\
\text { вий }\end{array}$ & $\begin{array}{c}\text { регі- } \\
\text { ональ- } \\
\text { ний }\end{array}$ & $\begin{array}{l}\text { дер- } \\
\text { жавний }\end{array}$ \\
\hline \multicolumn{5}{|c|}{ Надзвичайні ситуації техногенного характеру } \\
\hline Транспортні аварії & $(3 \phi) * *$ & $(3 \phi)$ & & \\
\hline Пожежі та вибухи & $(3 \phi)$ & $(3 \phi)$ & $3 \phi^{*}$ & \\
\hline $\begin{array}{l}\text { Аварії з викидом (загрозою } \\
\text { викиду СДОР, РР, БНР }\end{array}$ & & $(3 \phi)$ & $3 \phi$ & $3 \phi$ \\
\hline $\begin{array}{l}\text { Аварії на комунальних си- } \\
\text { стемах життєзабезпечення }\end{array}$ & $(3 \phi)$ & $3 \phi$ & $3 \phi$ & $3 \phi$ \\
\hline $\begin{array}{l}\text { Аварії на очисних спору- } \\
\text { дах }\end{array}$ & $3 \phi$ & $3 \phi$ & $3 \phi$ & $3 \phi$ \\
\hline Гідродинамічні аварії & & $(3 \phi)$ & $3 \phi$ & $3 \phi$ \\
\hline \multicolumn{5}{|c|}{ Надзвичайні ситуації природного характеру } \\
\hline $\begin{array}{l}\text { Геологічно та геофізично } \\
\text { небезпечні явища }\end{array}$ & $(3 \phi)$ & $(3 \phi)$ & $3 \phi$ & $3 \phi$ \\
\hline $\begin{array}{l}\text { Метеорологічні та агроме- } \\
\text { теорологічні небезпечні } \\
\text { явища }\end{array}$ & & & $(3 \phi)$ & $(3 \phi)$ \\
\hline $\begin{array}{l}\text { Пожежі лісові, степові, } \\
\text { сільськогосподарських ма- } \\
\text { сивів, корисних копалин }\end{array}$ & $(3 \phi)$ & $3 \phi$ & $3 \phi$ & $3 \phi$ \\
\hline Зміна стану суші & $(3 \phi)$ & $(3 \phi)$ & $3 \phi$ & $3 \phi$ \\
\hline
\end{tabular}

Примітка: $3 \phi^{*}$ - збитки, які необхідно обов'язково розраховувати; $(3 \phi)^{* *}$ - збитки, що стаються у деяких окремих випадках. Таблицю склав автор за матеріалом табл. 1. Основні види збитків, характерних для різних типів НС [6].

Розмір збитку для певних типів і видів надзвичайних ситуацій розраховують окремо для нафтопродуктів та інших речовин (окрім нафтопродуктів). Збитки від забруднення землі нафтопродуктами розраховують за такою формулою:

$$
3 \phi=Y_{n} \cdot n \cdot M \cdot L,
$$

де: $3 \phi$ - обсяг збитків від забруднення поверхні землі та грунтів, грн; $Y_{n}-$ питома величина збитків, завданих навколишньому природному середовищу, у НМД (розраховують за наявності інформації про об'єм забруднених підземних вод, або розраховують у разі забруднення підземних вод нафтопродуктами, в розрахунку на 1 тонну забруднювальної речовини); $n$ - розмір НМД, грн; $M$ - маса скинутої забруднювальної сировини, кг; $L$ - коефіцієнт, який враховує природну захищеність підземних вод.

Збитки від забруднення земель іншими (окрім нафтопродуктів) речовинами розраховують за такою формулою:

$$
\text { 3n.в. }=K_{i} \cdot Y_{n} \cdot n \cdot V_{3} \cdot L,
$$

де: 3n.в. - обсяг збитків від забруднення підземних вод, грн; $K_{i}$ - коефіцієнт небезпечності $i$-тої забруднювальної речовини; $Y_{n}-$ питома величина збитків, завданих навколишньому природному середовищу, в НМД; $n-$ розмір НМД, грн; $V_{3}$ - об'єм забруднених підземних вод, ${ }^{3} ; L-$ коефіцієнт, який враховує природну захищеність підземних вод.

Проаналізувавши показники процесу формування екологічного збитку, використаних для розрахунку збитків у формулах (1)-(3), можна з'ясувати оцінювальні підходи для розрахунку збитків у різних методиках. Так, у "Методиці визначення розмірів шкоди, зумовленої забрудненням і засміченням земельних ресурсів через порушення природоохоронного законодавства" [7] передбачено розрахунок прямого екологічного збитку, тоді як окремі методики розрахунку збитків від забруднення земель, наведені в "Методиці оцінки збитків від наслідків надзвичайних ситуацій техногенного і природного характеру" [6], призначені для визначення опосередкованого екологічного збитку від забруднення земель, а саме - збитку від забруднення підземних вод.

Опис подій техногенного характеру, спостереження за якими проводив Департамент з питань цивільного захисту, зокрема витоків дизельного палива із систем трубопроводів на території Львівської області, які відбулися впродовж 2005-2012 рр. (табл. 3), не містить інформації про забруднення підземних вод.

Розрахувати збиток від забруднення земель внаслідок транспортних аварій (див. табл. 3), відповідно до "Методики оцінки збитків від наслідків надзвичайних ситуацій техногенного і природного характеру" [6], виявляється неможливим 3 причини відсутності показників опосередкованого екологічного збитку, а саме - забруднення підземних вод.

Інформація про забруднення підземних вод може бути відсутня при описі подій надзвичайного характеру з таких причин:

1) у разі забруднення земель не завжди є забруднення підземних вод;

2) складність та проблематичність встановлення факту забруднення підземних вод.

Отже, наявні методики для розрахунку збитку від забруднення земель, які передбачають визначення опосередкованого екологічного збитку, малоефективні, оскільки розрахувати збиток виявляється можливим тільки за наявності інформації про забруднення наприклад, підземних вод. 
Табл. 3. Наслідки забруднення природних об'єктів від витоків дизельного палива із системи трубопроводів на території Львівської області, які відбулися впродовж 2005-2012 pp.

\begin{tabular}{|c|c|c|c|c|}
\hline \multirow[b]{2}{*}{ № } & \multirow[b]{2}{*}{$\begin{array}{l}\text { Дата ви- } \\
\text { току }\end{array}$} & \multirow{2}{*}{$\begin{array}{c}\text { Приб- } \\
\text { лизна } \\
\text { маса } \\
\text { витоку }\end{array}$} & \multicolumn{2}{|c|}{ Забруднення природних об'єктів } \\
\hline & & & $\begin{array}{c}\text { земель, грунту } \\
\text { (площа забруд- } \\
\text { нення) }\end{array}$ & водні об'єкти \\
\hline 1 & 29.06 .05 & $2 \mathrm{~T}$ & $20 \mathrm{M}^{2}$ & $\begin{array}{c}\text { p. Зубра, яка впадає в } \\
\text { p. Дністер }\end{array}$ \\
\hline 2 & 16.07 .05 & $4 \mathrm{~T}$ & & $\begin{array}{c}\text { лісове озеро розміром } \\
2500 \text { м² за межами охо- }^{\text {ронної зони }}\end{array}$ \\
\hline 3 & 17.07 .06 & $5 \mathrm{~T}$ & $100 \mathrm{M}^{2}$ & p. Бар \\
\hline 4 & 21.10 .06 & 150 л & $+*$ & \\
\hline 5 & 16.11 .06 & & & $\begin{array}{l}\text { p. Чукв'янка, яка впа- } \\
\text { дає в р. Дністер }\end{array}$ \\
\hline 6 & 21.03 .07 & & + & р. Дністер \\
\hline 7 & 01.11 .07 & & + & \\
\hline 8 & 19.01 .08 & & + & $\begin{array}{c}\text { струмок у с. Ясениця- } \\
\text { Замкова Старосам- } \\
\text { бірського району }\end{array}$ \\
\hline 9 & 18.05 .08 & 1000 л & $163 \mathrm{~m}^{2}$ & \\
\hline 10 & 11.12 .09 & & $18 \mathrm{~m}^{2}$ & \\
\hline 11 & 02.02 .11 & & $250 \mathrm{M}^{2}$ & \\
\hline 12 & 15.04 .11 & & + & \\
\hline 13 & 21.05 .11 & & $20 \mathrm{~m}^{2}$ & \\
\hline 14 & 03.08 .11 & & $15 \mathrm{~m}^{2}$ & $\begin{array}{c}\text { p. Струга та p. Верещи- } \\
\text { ця }\end{array}$ \\
\hline 15 & 05.11 .12 & & $4 \mathrm{~m}^{2}$ & \\
\hline 16 & 05.12 .12 & 40 л & $50 \mathrm{M}^{2}$ & \\
\hline
\end{tabular}

Примітка: +* - площу забруднення не встановлено. Авторська розробка за матеріалами "Регіональних доповідей про стан НПС у Львівській області" у 2005-2012 рр.

\section{Висновки}

З'ясовано, що збитки від забруднення земель можуть бути розраховані як прямі й опосередковані за окремими методиками. Встановлено, що наявні методики для визначення опосередкованого екологічного збитку від забруднення земель, зокрема методики оцінювання збитків від наслідків надзвичайних ситуацій, малоефективні, оскільки за відсутності інформації про забруднення підземних вод розрахувати збиток виявляється неможливим. Також встановлено, що дещо ефективнішою методикою для розрахунку збитків від забруднення земель $є$ методика, яка визначає прямий збиток.

Запропоновано, в Україні надалі для оцінювання економічного збитку від забруднення земель потрібно використовувати тільки одну ефективну методику, розроблену для розрахунку збитків від забруднення земель через порушення природоохоронного законодавства.

Перспективи подальших досліджень необхідно спрямувати на вдосконалення чинної методики для розрахунку збитку від забруднення земель через порушення природоохоронного законодавства.

\section{References}

1. Bublyk, M. I., \& Koropetska, T. O. (2010). Ekspertni metody otsinky vtrat vid nadzvychainykh sytuatsii tekhnohennoho kharakteru Visnyk NU "Lvivska politekhnika", 668, 235-245. [In Ukrainian].

2. Bublyk, M. I., Syplyvchak, O. I. (2009). Teoretychnyi analiz metodiv, yaki zastosovuiut dlia otsinky tekhnohennykh zbytkiv. Scientific Bulletin of UNFU, 9. 144-149. [In Ukrainian].

3. Kolmakova, V. M. (2018). Ekosystemnyi pidkhid do otsiniuvannia zbytkiv vid zabrudnennia vodnykh resursiv. Biznes-navihator, 44, 67-70. [In Ukrainian].

4. Kuzmin, O. Ye., Bublyk, M. I., \& Rybytska, O. M. (2014). Model ekonomichnoho otsiniuvannia tekhnohennykh zbytkiv $\mathrm{v}$ natsionalnomu hospodarstvi za chynnykamy vplyvu, spryiniattia y otsiniuvannia. Ekonomichni innovatsii, 58, 138-143. [In Ukrainian].

5. Naumova, T. V. (2005). Kontseptualnye osnovy otsenky jekolohycheskoho ushcherba. Nauchnyi vestnyk MHTU HA, 86. [In Russian].

6. Pro zatverdzhennia Metodyky otsinky zbytkiv vid naslidkiv nadzvychainykh sytuatsii tekhnohennoho i pryrodnoho kharakteru. (2002). Postanova Kabinetu Ministriv Ukrainy vid 15.02.2002 r., № 175. Zakonodavstvo Ukrainy: baza danykh. Verkhovna Rada Ukrainy. Retrieved from: https://zakon.rada.gov.ua/laws/show/175-2002-\%D0\%BF (Date of application: 12.10.2020). [In Ukrainian].

7. Pro zatverdzhennia Metodyky vyznachennia rozmiriv shkody, zumovlenoi zabrudnenniam i zasmichenniam zemelnykh resursiv cherez porushennia pryrodookhoronnoho zakonodavstva. (1998). Nakaz Ministerstva okhorony navkolyshnoho pryrodnoho seredovyshcha ta yadernoi bezpeky Ukrainy vid 05.05.1998 r., № 285/2725. Zakonodavstvo Ukrainy: baza danykh. Verkhovna Rada Ukrainy. Retrieved from: https://zakon.rada.gov.ua/laws/show/z0285-98 (Date of application: 13.10.2020). [In Ukrainian].

8. Pro zatverdzhennia Poriadku i pravyl provedennia oboviazkovoho strakhuvannia tsyvilnoi vidpovidalnosti subiektiv hospodariuvannia za shkodu, yaka mozhe buty zapodiiana pozhezhamy ta avariiamy na obiektakh pidvyshchenoi nebezpeky, vkliuchaiuchy pozhezhovybukhonebezpechni obiekty ta obiekty, hospodarska diialnist na yakykh mozhe pryzvesty do avarii ekolohichnoho i sanitarno-epidemiolohichnoho kharakteru. (2002). Postanova Kabinetu Ministriv Ukrainy vid 16.11.2002 r., № 1788. Zakonodavstvo Ukrainy: baza danykh. Verkhovna Rada Ukrainy. Retrieved from: https://zakon.rada.gov.ua/laws/show/1788-2002-\%D0\%BF\#Text. [In Ukrainian].

9. Saleem, H. Ali, Jose, A., \& Puppim, de Oliveira. (2018). Pollution and economic development: an empirical research review. Environmental Research Letters, 13, 1-14. https://doi.org/10.1088/1748-9326/aaeea7

10. Tupulov, A. S. (2014). Metodologicheskie voprosy otcenki ushherba ot zagriazneniia okruzhaiushhei sredy. Regionalnye problemy preobrazovaniia ekonomiki, 9(47), 133-140. [In Russian].

11. Veklych, O. O. (2018). Ekosystemnyi pidkhid otsiniuvannia ekonomichnoho zbytku vid zabrudnennia navkolyshnoho pryrodnoho seredovyshcha: ukrainska avtentychnist. Ekonomika Ukrainy, 4, 63-75. [In Ukrainian].

12. Zubko, K. Yu. (2017). Otsinka naslidkiv antropohennoho vplyvu na pryrodu i suspilstvo. Ekonomika i suspilstvo: elektron. nauk. fakhove vyd., 9. Retrieved from: http://economyandsociety.in.ua/journal/9_ukr/144.pdf. [In Ukrainian].

N. M. Grynchyshyn

Lviv State University of Life Safety, Lviv, Ukraine

\section{THE EFFECTIVENESS OF THE METHODOLOGY FOR CALCULATING THE DAMAGE FROM LAND POLLUTION IN UKRAINE}

The economic mechanism of environmental management from the standpoint of environmental safety provides for compensation for environmental damage from pollution of components of the natural environment. In Ukraine, the determination of economic da- 
mage from pollution is carried out in cases of violation of environmental legislation by business entities and to assess the consequences of man-made and natural emergencies. To eliminate misunderstanding in the amount of damage from land pollution, calculated using various methods, it is necessary to determine one effective method. It is known that economic damage from pollution is formed by the factors of influence, perception and condition. Influence and perception factors form environmental damage. The effectiveness of the methodology is determined by the ability to calculate quickly the damage using the most informative indicators of the factors of the formation of environmental damage. In the methodology for calculating damage from land pollution for violations of environmental legislation by business entities, a direct approach was used applying the most informative indicators of factors in the formation of environmental damage from land pollution. In the methods for calculating damage from land pollution to assess the consequences of man-made and natural emergencies, an indirect approach is used which applies indicators describing the consequences of secondary land pollution, namely, groundwater pollution. According to the research results, the methodology for calculating damage from land pollution for violations of environmental legislation by business entities is more effective compared to methods for calculating damage from land pollution caused by technogenic and natural emergencies. To assess the economic damage from land pollution in Ukraine, it is recommended to use one, the most effective methodology designed to calculate damage from land pollution for violations of environmental legislation by business entities.

Keywords: land resources; environmental damage; economic assessment of pollution damage; factors of influence and perception. 